\title{
MELIHAT SEJARAH NASIONALISME INDONESIA UNTUK MEMUPUK SIKAP KEBANGSAAN GENERASI MUDA
}

\author{
Mifdal Zusron Alfaqi \\ Peneliti di Pusat Studi Budaya dan Laman Batas Universitas Brawijaya Malang \\ mifdal.um@gmail.com
}

\begin{abstract}
In the globalized era and the fragile nation, it is necessary for us to look backward (to learn) the history of Indonesian nationalism. It is due to the fact that in this era a lot of young generation tends to forget and choose to become competitive individuals and then ignore their nationality. Many young generations were trapped in temporary hedonism and rejected national spirit in the name of personal objectives. From the formation of Indonesian nationalism perspective, the role of young generation is inseparable such as Sumpah Pemuda (Youth Pledge). Accordingly, by considering the history of Indonesia nationalism, it is necessary for young generation to have an attitude as well as behave in the context of nationality.
\end{abstract}

Keywords: nationalism, history, Sejarah Nasionalisme Indonesia, nationality, young people

\section{PENDAHULUAN}

Nasionalisme adalah sebuah kata yang tidak asing lagi terdengar di telinga kita, karena pada dasarnya nasionalisme sudah ada sebelum Indonesia merdeka. Beberapa studi kasus tentang nasionalisme sudah sering terjadi, sebagai contoh di Skotlandia. Skotlandia adalah negara yang telah berada di bawah kekuasaan Kerajaan Inggris selama 300 tahun lamanya telah menguasai Skotlandia. Kini Skotlandia telah bebas dan merdeka. Kemerdekaan dapat terjadi karena di Skotlandia mengadakan referendum dengan cara pemilihan langsung (voting), dengan hasil lima puluh satu persen (51\%) rakyat memilih untuk bebas dan pisah dari Britania Raya.

Berdasarkan studi kasus tersebut menunjukkan bahwa terdapat dua hal penting, yaitu kesatuan wilayah yang harus dipertahankan dan kekuasaan rakyat yang dibentuk atas semangat persatuan ternyata dapat menentukan arah, tujuan, serta cita-cita suatu bangsa. Adanya semangat persatuan pada rakyat Skotlandia memperlihatkan telah terjadi nasionalisme di antara mereka. Apabila ditarik pada jaman kekinian, maka nasionalisme tersebut dapat menjadi modal besar dan utama untuk menjaga eksistensi dan menjaga konsistensi dari kedaulatan suatu negara. Hal tersebut menjadi perlu karena dengan adanya sikap nasionalisme yang tinggi maka akan mewujudkan kedaulatan bangsa yang kuat.

Salah satu yang harus ditumbuhkan sikap nasionalismenya adalah generasi muda, karena merekalah kelak yang akan membawa bangsa ke depan. Melihat sejarah tentang bagaimana nasionalisme terbentuk di Indonesia maka generasi muda akan mendapatkan sebuah gambaran dan akan mengetahui maksud dari terbentuknya nasionalisme Indonesia.

Penggambaran Benedict Anderson melalui komunitas-komunitas terbayangnya melihat dan memahami studi kasus yang telah disajikan sebelumnya merupakan semangat persatuan atau kebangsaan yang dalam hal ini 
nasionalisme adalah sesuatu yang abstrak. Hal tersebut memberikan penjelasan bahwa bangsa adalah sesuatu yang terbayang, karena persatuan yang telah terbangun mengalami benturan dengan dimensi ruang dan waktu dalam wadah bangsa. Nasionalisme merupakan semangat kebangsaan atau persatuan dalam perkembangannya dijadikan sebuah paham yang menempatkan persatuan dari berbagai elemen sebagai sesuatu yang vital ada dalam jiwa setiap individu yang bernaung dalam suatu komunitas. Keadaan semacam itulah yang telah diterima menjadi sebutan ideal dalam bentuk komunitas yang lebih besar. Melihat kajian tersebut, dalam kajian ini perlu diberikan penjelasan khusus mengenai pengertian nasionalisme dari berbagai macam ahli, yang diawali dengan pemahaman terhadap istilah "bangsa".

Menurut Mochtar Pabotinggi pengertian bangsa dan nation itu berbeda. Bangsa adalah kolektivitas sosiologis, sementara nation adalah kolektivitas politik. Perbedaan istilah bangsa dan nation bagi Daniel Dhakidae tidak mudah untuk diterima dan sulit untuk dibuat nalarnya. Pemahaman mengenai bangsa dan nation agar mudah untuk dipahami, Daniel Dhakidae membuat pengertian pembanding dengan menggunakan analisis Karl Mark yang menyebutkan bahwa rakyat adalah sesorang yang senantiasa berhubungan dengan kekuasaan, dimana kedaulatan dipegang oleh raja dan menyamakan rakyat dengan kuda-kudanya .

Berdasarkan analisis Karl Mark, nation dianggap tidak memiliki hubungan tersebut. Hal itu dapat terjadi karena nation dianggap sebagai komunitas yang mempunyai kedaulatan, sedangkan kebangsaan merupakan sesuatu yang merujuk pada sifat atau ciri-ciri dari sebuah komunitas yang disebut dengan bangsa. Menurut beberapa ahli, kebangsaan adalah sifat dari sebuah komunitas bangsa yang memiliki sesuatu yang unik. Keunikan tersebut terletak pada kesatuan masing-masing perasaan yang dimulai dari tataran komunitas dalam lingkup yang sempit hingga komunitas besar yang kemudian disebut dengan bangsa. Karakter kebangsaan masing-masing komunitas bisa ada karena adanya persamaan nasib, karakter, maupun sejarah. Sedangkan rasa kebangsaan bisa ada karena merujuk pada sebuah kesadaran terhadap komunitasnya yang bersatu. Kesadaran tersebut memiliki tingkatan yang lebih tinggi dalam memaknai pembentukan nasionalisme.

Pengertian nasionalisme dari satu ahli dengan ahli yang lain berbeda-beda. Berdasarkan hal tersebut, kemudian muncul gagasan-gagasan tentang nasionalisme yang berbeda-beda. Adanya perbedaan dalam memaknai gagasan tersebut maka beberapa ahli melakukan pengkajian. Beberapa ahli memandang nasionalisme adalah paham yang unik. Keunikan dari nasionalisme tergambar dari ketotalitasan sebuah kondisi dalam wadah bangsa yang tidak mempedulikan akan ketidakadilan, penjajahan, penghisapan yang mungkin terjadi. Menurut Tonnies (Dhakidae, 2001) ketotalitasan didasarkan pada kesetiakawanan, persaudaraan, kekeluargaan, dan mungkin persamaan bisa tergabung di dalamnya.

Beberapa ahli telah mengemukakan teori tentang nasionalisme dengan berbagai latar yang berbeda-beda, diantaranya Karl Friedrich von Savigny dengan Historical School-nya bahwa setiap bangsa memiliki semangat yang unik, yaitu semangat kebangsaan (Volksgeist). Semangat kebangsaan inilah yang dipandang unik sehingga harus menjadi prinsip pembangunan sebuah negara. Nasionalisme yang digagas 
Savigny ini mengungkapkan bahwa nasionalisme ini bukan sesuatu yang abstrak universal tapi sesuatu yang jelas dan khusus. Anderson (2001) berpendapat bahwa nasionalisme belandaskan persatuan dari komunitas-komunitas yang dibayangkan. Kesatuan ini disatukan oleh sebuah persaudaraan yang setara sehingga menciptakan entitas yang utuh. Nasionalisme terbentuk dari kesamaan stimulus sehingga perasaan kebangsaan yang terbentuk adalah sama. Sementara itu Smith (1991) memberikan pengertian nasionalisme adalah kualitas dan integritas kesadaran nasional warga bangsa, atau suatu bangsa definisi nasionalismenya dengan menyatakan bahwa nasionalisme ada sebelum lahirnya bangsa karena sudah ada dalam diri etnis yang kemudian mendorong mereka untuk membentuk negara sendiri.

\section{SEJARAH NASIONALISME INDONESIA}

Seperti yang sudah dipaparkan sebelumnya bahwa nasionalisme bukan menjadi barang baru bagi bangsa Indonesia. Banyak karya-karya baik tulisan maupun penelitian yang membahas tentang sejarah nasionalisme di Indonesia. Dasar kebangsaan Indonesia yang telah disampaikan oleh Soekarno dalam pidato lahirnya Pancasila juga membahas tentang nilai-nilai nasionalisme. Ketika membahas tentang sejarah nasionalisme kita dapat melakukan penelusuran jauh ke belakang lagi dengan kajian yang dilakukan oleh Dhont, (2005), tentang bagaimana benih-benih nasionalisme di Indonesia mulai bergelora ketika era pergerakan nasional (periode 1920-an) yang pada saat itu adalah sebagai wujud dari adanya sebuah sistem politik yang diterapkan oleh pemerintah hindia belanda yaitu sebuah sistem politik etis yang kemudian pada akhirnya menjadi salah satu bukti bahwa nasionalisme telah ada di Indonesia. Di sisi lain kita juga dapat melihat apa yang telah dipaparkan oleh Niwandhono (2011) bahwa nasionalisme jauh telah ada sejak adanya kebudayaan Indis. Namun, dari beberapa pemaparan tentang sejarah nasionalisme yang telah dilakukan oleh para peneliti tersebut, ternyata secara eksplisit ada sebuah kesepakatan bulat yang menyatakan benihbenih nasionalisme ataupun faktor-faktor pembangun nasionalisme adalah karena terjadi sebuah penjajahan sebelumnya pada suatu komunitas bangsa.

Perkembangan nasionalisme yang ada di Indonesia kalau meminjam istilah yang telah disampaikan oleh Kahin (2013) yang menyatakan pertumbuhan embrionya berjalan secara laten memang bisa dirasionalkan. Dari beberapa catatan sejarah yang ada dikatakan bahwa nasionalisme sudah ada di Nusantara sejak kerajaan Majapahit berkuasa. Semangat nasionalisme pada saat itu telah digelorakan oleh Maha Patih Gajah mada dengan visi globalisasinya yaitu yang terkenal dengan istilah "Sumpah Palapa" yang bertujuan untuk menyatukan wilayah Majapahit dengan seluruh wilayah Nusantara. Melalui kajian yang telah dilakukan oleh Niwandhono juga dapat merekam tentang jejak-jejak nasionalisme yang ada di Nusantara, yaitu dimulai dari periode nasionalisme Indis (Indisch Nationalisme). Niwandhono (2011) memberikan sebuah definisi tentang nasionalisme yaitu, Nasionalisme Indis adalah suatu kesadaran yang dilatarbelakangi oleh persoalan yang muncul dalam wilayah orang-orang Eropa atau Indis (sebutan untuk kelompok masyarakat Eropa di Indonesia yang telah mengalami hibridasi baik secara biologis maupun sosio-kultural). Perlawanan 
yang dilakukan terhadap pemerintah Belanda ini didasari oleh persamaan bahasa dan leluhur yang dialami oleh orang-orang Indis tersebut.

Untuk memahami seberapa besar pengaruh nasionalisme Indis yang berlangsung di tahun 1800an terhadap nasionalisme Indonesia. Maka hal tersebut perlu untuk dijelaskan secara gamblang, mengingat gerakan-gerakan ini dilakukan oleh para keturunan Belanda dengan gundiknya. Namun yang perlu diingat adalah unsur hibriditas mereka juga perlu dipertimbangkan, walaupun mereka tersebut berdarah Eropa tapi secara status dan sosiokultural mereka seperti orang pribumi, bahkan Niwandhono (2011) menyebut Indis adalah embrio dari identitas kebangsaan yang kemudian disebut Indonesia. Dari nasionalisme Indis ini muncul tokoh-tokoh seperti Douwes Dekker dan para pendiri Indische Partij (IP) serta melahirkan tokoh yang disebut tiga serangkai pelopor nasionalisme (Eduard Douewes Dekker, Tjipto Mangoenkusumo, dan Soewardi Soerjaningrat). Gerakan ini merupakan gerakan yang bertujuan untuk menuntut hak kewarganegaraan mereka di sisi lain gerakan ini juga menjadi sebuah perintis gerakan oposisi terhadap pemerintah kolonial yang terorganisir. Propaganda yang dilakukan ini pada akhirnya berdampak luar biasa. Bagaimana tokoh-tokoh penggerak antara lain Douwes Dekker alias Maltatuli dengan Max Havelarnya, sebuah tulisan yang mengkritik ekploitasi pemerintah kolonial. Kemudian Soewardi Soerjaningrat dengan tulisan berjudul Als ik eens Nederlander was (andai aku seorang Belanda) yang mengkritik perayaan 100 tahun kemerdekaan Belanda dari Perancis.
Nasionalisme Indis yang seperti disampaikan di atas adalah sebuah gerakan yang menjadi awal mula benih nasionalisme Indonesia memang tepat. Namun, nasionalisme Indis bukanlah satu-satunya yang mejadi tonggak awal lahirnya nasionalisme di Indonesia. Modernisasi yang dilakukan oleh pemerintah kolonial Hindia Belanda terhadap orang-orang jajahannya juga menjadi faktor pendorong yang besar pula. Berdasarkan dengan adanya modernisasi tersebut maka lahirlah politik etis yang membawa perubahan besar yang akhirnya memberikan kesempatan kepada orang-orang pribumi untuk mengenyam pendidikan baik didalam negeri maupun ke luar negeri. Perhimpunan Indonesia (Indonesische Vereeniging) yang merupakan wadah perhimpunan mahasiswa-mahasiswa Indonesia yang ada di Belanda berhasil menjadi sebuah kawah candradimuka yang pada akhirnya membentuk nasionalisme bagi orang-orang Indonesia yang dikemudian hari menjadi tokoh-tokoh pergerakan nasional, sebagai contoh seperti Soewardi Soerjaningrat, Tjipto Mangoenkosumo, Muhammad Hatta, Sutan Sahjrir, Sutomo, dan Sartono. Melihat sebuah kajian yang dilakukan oleh Dont, seorang berkebangsaan Belgia yang menempuh studi di Universitas Gadjah Mada, menyatakan bahwa Perhimpunan Indonesia memiliki andil yang sangat besar dalam pembentukan beberapa organisasi-organisasi di Indonesia, seperti Algemeene Studie Club yang berada di Bandung dan Soekarno ada di dalamnya, kemudian Indonesische Studieclub yang berada di Surabaya. Kemudian Perhimpunan Indonesia juga mempunyai sebuah peran yang sangat besar terhadap terselenggaranya kongres pemuda ke II pada tanggal 28Oktober 1928 yang kemudian lahir sebuah cerita 
heroik tentang persatuan pemuda yang biasa dikenal dengan sumpah pemuda.

Beberapa gambaran tentang sejarah nasionalisme yang telah dipaparkan di atas diperkuat kembali dengan penelitian yang dilakukan oleh Kahin, seorang yang berkebangsaan Amerika yang pernah juga menjadi serdadu pada perang dunia II. Dia mengidentifikasi banyak hal tentang perkembangan nasionalisme sejak HindiaBelanda. Penelitian yang dilakukan sejak tahun 1948 ini semakin menguatkan bahwa nasionalisme adalah antitesis dari sebuah penjajahan (2013). Dari penelitian ini terungkap fakta bahwa bangsa Indonesia tidak hanya dijajah oleh kongsi dagang VOC dan pemerintah kolonial saja, namun secara bersamaan juga oleh Cina dan bangsa Indonesia lainnya yang diwakili oleh kaum ningrat. Dalam Fakta sejarah tersebut cukup jelas menyebutkan bahwa VOC datang karena ketertarikan dengan rempah-rempah yang terdapat di Maluku hingga terjadi berbagai monopoli di sektor ekonomi. Ketika pemerintah Belanda turut campur tangan karena terjadi ketidakstabilan ekonomi di internal VOC, eksploitasi sumber daya manusia maupun alamnya semakin menjadijadi. Dengan siasat menguasai para kaum ningrat inilah Belanda dapat mengusai para petani beserta tanahnya tanpa menghadapi gejolaknya. Di sisi lain Belanda membawa orang-orang Cina sebagai mitra dagangnya.

Kondisi menggambarkan bahwa rakyat Indonesia yang disebut sebagai pribumi, meminjam istilah dari Kahin, benar-benar mengalami isolasi ekonomi, sosial, dan psikologis. Wajar penggambaran tersebut diutarakan, melihat sistem tanam paksa, pajak tanah, kewajiban menyerahkan hasil panen, terisolasi dari pasar dan perlakuan semenamena oleh penjajah begitu menjatuhkan nasib orang-orang pribumi kedalam dasar kesengsaraan. Praktik-praktik feodalistik semacam itu terus-menerus dilakukan sebagai upaya pemerasan sebesar-besarnya untuk menunjang perekonomian Belanda yang di Eropa sedang menghadapi era industrialisasi dan sangat membutuhkan daya kapital yang luar biasa. Di wilayah Hindia-Belanda sendiri praktik "penjilatan" yang dilakukan oleh kaum ningrat yang menjadi antek-antek Belanda memang dibuat sedemikian rupa, karena selain sebagai agen agitasi Belanda kepada orang-orang pribumi, mereka juga dijanjikan akan kedudukan dan kekuasaan. Isolasi ekonomi, sosial, dan psikologis sekali lagi jelas terpampang dari uraian tersebut.

Tidak harus kita melihat cara-cara represif pemerintah kolonial Belanda sebagai bentuk kekejian yang mutlak. Benih nasionalisme inilah yang tersemai karena pembatasanpembatasan politis yang dilakukan oleh pemerintah kolonial. Memang serakah, namun di sinilah titik balik yang kemudian akan membangun kesadaran nasional dan membentuk jiwa-jiwa patriotik yang dimulai dari patriotik lokal hingga menjadi sebuah patriotik kesatuan. Dibukanya interaksi antara orang-orang pribumi dengan pemerintah kolonial Belanda membuat orang-orang pribumi ini, khususnya petani, melek mata melihat sebuah ketimpangan dan kesenjangan ekonomi, sosial maupun kultural dengan para kaum penjajah. Kesadaran ini mengakibatkan orientasi individualistik yang mulai terjadi penerimaan-penerimaan gagasan nasionalisme dikalangan petani. Hal tersebut sangat besar dipengaruhi oleh pergantian sistem eksploitasi ekonomi secara tidak langsung seperti sistem tanam paksa menjadi sistem usaha bebas yang dikelola secara langsung, banyak sektor dalam kehidupan agraris mulai berhubungan dengan orang 
Belanda maupun kekuatan ekonomi Belanda (Kahin, 2013, pp. 56-57).

Kesadaran akan kekuasaan politik dan ekonomi Belanda membangun jiwa nasionalisme. Kesepakatan di awal bahwa nasionalisme dibentuk atas kesamaan nasib, karakter, kultural maupun sejarah. Dalam kesepakatan ini melalui penelusuran dari penelitian Kahin yang mengambil objek kajian nasionalisme Indonesia telah dibuktikan. Kahin (2013, p. 55) menyatakan awal mula nasionalisme Indonesia tidak dapat diperkirakan. Awal nasionalisme Indonesia merupakan fase yang baru mulai disuarakan dan diorganisir pada dasawarsa kedua abad ke-20. Terdapat lima unsur yang membuat pertumbuhan nasionalisme Indonesia. Pertama, tingginya homogenitas keagamaan di Indonesia. Dengan komposisi hampir 90 persen penduduk Indonesia beragama Islam, akan mudah membangun solidaritas. Selain untuk menangkal kristenisasi, Islam yang berdiri tipis diatas kebudayaan Hindu-Budha dan mistisme Jawa, semakin mempermudah penerimaannya di tataran rakyat, khususnya rakyat Jawa; Kedua, sikap superioritas orangorang Belanda yang tidak mau disamakan dengan orang pribumi dalam berbahasa menjadi faktor integrasi penting lainnya. Perkembangan bahasa persatuan (lingua franca) yang digunakan adalah bahasa Melayu mampu menghancurkan solidaritassolidaritas sempit dalam nasionalisme Indonesia; Ketiga, dengan dibentuknya majelis perwakilan tertinggi bagi orang Indonesia yang disebut Volksraad, mampu mengorganisir gerakan-gerakan kebangkitan nasional meskipun banyak yang berpendapat posisi Volksraad tidak begitu berpengaruh di mata pemerintah kolonial Belanda; Keempat, perkembangan radio dan surat kabar menjadi saluran untuk penyebaran gagasan nasionalisme. Beberapa study club yang berdiri, misal: Perhimpunan Indonesia membuat surat kabar yang diberi nama Oetosan Hindia untuk menyebarkan nasionalisme dan sebagai alat propaganda politik; Kelima, adanya rangsangan oleh mobilitas geografis gagasan maupun penduduk. Dengan pertumbuhan penduduk yang meningkat sebagai akibat dari pola organisasi ekonomi maupun fasilitas transportasi abad ke-20 di Indonesia, mobilitas ini begitu berpengaruh sebagai faktor penyebab integrasi.

Penyemaian benih-benih nasionalisme telah dilakukan begitu hebat dan lama serta telah mengalami berbagai kondisi yang memungkinkan nasionalisme itu lenyap oleh kekuasaan kolonial, namun sejarah menjadi saksi akan keteguhan bangsa Indonesia akan persamaan nasib telah mampu menahan gempuran penjajah. Dimulai dari berkembangnya nasionalisme Indis yang juga menyokong tumbuhnya nasionalisme Indonesia dan kemudian dengan dikeluarkannya politik etis, nasionalisme yang digagas oleh intelektual muda yang kemudian menjadi tokoh pergerakan menjadi sebuah dinamika sejarah nasionalisme Indonesia. Proklamasi 17 Agustus 1945 adalah salah satu bukti sejarah perkembangan nasionalisme yang telah berada pada level yang lebih tinggi, lahirnya Pancasila turut menjadi saluran perkembangan dan transformasi nasionalisme untuk bangsa Indonesia. Ide persatuan yang disampaikan Soekarno dalam pidato lahirnya Pancasila, semakin mempertegas bahwa nasionalisme adalah sebuah keniscayaan bagi bangsa Indonesia dengan melihat bangsa ini merupakan serangkaian heterogenitas yang berdiri atas persamaan, kesadaran dan kehendak untuk bersatu. 


\section{SIMPULAN}

Nasionalisme merupakan sesuatu yang sangat penting bagi kehidupan berbangsa dan bernegara. Karena dengan nasionalisme yang tinggi sebuah bangsa dapat berdiri tegak dan memiliki sebuah jati diri yang kuat. Nasionalisme merupakan sesuatu yang harus diperhatikan oleh setiap elemen bangsa dalam setiap perjalanan bangsa tersebut, begitu pula dengan Indonesia. Indonesia memulai istilah nasionalisme jauh sebelum Indonesia terbentuk.

Ketika membicarakan tentang sejarah nasionalisme Indonesia tentu kita tidak boleh melupakan salah satu pembentuk nasionalisme Indonesia yaitu orang-orang Indis. Dalam sejarah nasionalisme sering hanya dikaitkan dengan para tokoh-tokoh kemerdekaan saja, atau kita hanya memandang nasionalisme hanya terpaku pada sudut kecil yaitu tokoh. Padahal kalau kita kaji lebih jauh ternyata banyak factor yang akhirnya membentuk nasionalisme Indonesia. Seperti yang telah digambarkan di atas bahwa nasionalisme Indonesia tumbuh jauh sebelum Negara Indonesia tertentu, seperti "sumpah palapa" yang digelorakan oleh Maha Patih Gadjah Mada yang bertujuan untuk menyatukan nusantara, kemudian lahirnya nasionalisme Indis yang dilakukan oleh orang darah Eropa yang mengalami hibridasi dengan bangsa pribumi. Nasionalisme Indis tentu memberi peran penting bagi lahirnya Nasionalisme Indonesia, karena munculnya nasionalisme Indis merupakan bentuk dari penolakan dari adanya kolonialisme yang akhirnya melahirkan beberapa produk yang akhirnya membantu membentuk nasionalisme. Kemudian politik Etis Pemerintah hindia Belanda yang pada akhirnya melahirkan Perhimpunan Indonesia juga sangat memberikan pengaruh terhadap nasionalisme Indonesia. Kemudian dengan beberapa peristiwa tersebut dapat diambil kesimpulan bahwa nasionalisme adalah alat untuk penolakan adanya penjajahan atau sebagai antitesis sebuah penjajahan tersebut.

Langkah strategis ke depan bangsa Indonesia harus menumbuhkan nilai-nilai nasionalisme yang lebih kuat kepada generasi muda penerus bangsa ini ke depan. Karena akibat dari lunturnya nilai-nilai nasionalisme mengalami berbagai macam masalah. Bangsa Indonesia mengalami berbagai macam masalah mulai dari kekerasan, isu SARA, serta masalah-masalah Hak Asasi Manusia (HAM). Masalah-masalah tersebut tentunya terjadi dari lunturnya nilai-nilai nasionalisme. Di sisi lain generasi muda bangsa ini malah mengalami berbagai macam masalah seperti adanya tawuran antar pelajar, masalah narkoba, seks bebas dan lain sebagainya. Akibat dari beberapa masalah tersebut seakan memperlihatkan bahwa bangsa Indonesia seakan keluar dari jati dirinya sebagai bangsa yang memiliki keberagaman dan kesantunan. Dengan menumbuhkan sikap nasionalisme yang lebih kuat kepada generasi muda maka bangsa Indonesia akan bisa keluar dari berbagai macam masalah yang dialami, karena kalau kita berkaca dari sejarah generasi muda selalu menjadi sebuah pelopor berubahnya bangsa ini mulai dari jaman kolonialisme sampai era reformasi. Dengan menumbuhkan sikap nasionalisme yang tinggi maka bangsa Indonesia kedaulatan yang kuat dan pada akhirnya bangsa Indonesia bisa mewujudkan cita-citanya yaitu sebuah Negara yang adil dan makmur.

\section{DAFTAR PUSTAKA}

Anderson, B. (2001). Imagined communities: Komunitas-komunitas terbayang.(Terj). (O. I. Naomi, Trans.). Yogyakarta: Pustaka Pelajar dan Insist. 
Dhakidae, D. (2001). Sistem sebagai totalisasi, masyarakat warga, dan pergulatan demokrasi. In S. Sularto (Ed.), Masyarakat warga dan pergulatan demokrasi (pp. 3-29). Jakarta: Kompas Gramedia.

Dhont, F. (2005). Nasionalisme baru intelektual Indonesia tahun 1920-an. Yogyakarta: Gadjah Mada University Press.

Kahin, G. M. (2013). Nasionalisme dan revolusi Indonesia. (D. Anggraeni, I. Adilah, \& T. Agrippina, Eds., Tim Komunitas Bambu, Trans.). Depok: Komunitas Bambu.

Niwandhono, P. (2011). Yang ter (di) lupakan: kaum Indo dan benih nasionalisme Indonesia. Yogyakarta: Djaman Baroe.

Smith, A. D. (1991). National identity. University of Nevada Press. 